Zoologica Poloniae (2013) 58/3-4: 87-98

DOI: $10.2478 /$ zoop-2013-0007

\title{
THE RESULTS OF THE INVENTORY OF COMMON HAMSTER (CRICETUS CRICETUS L.) SITES CONDUCTED IN MALOPOLSKA VOIVODESHIP
}

\author{
Paulina StrejczeK ${ }^{1}$ and Magdalena HędrzaK ${ }^{2 *}$ \\ ${ }^{1}$ Environmental Education, www.sowkaart.pl, Kraków, \\ e-mail: strejczek_paulina@op.pl \\ ${ }^{2}$ University of Agriculture in Kraków, Department of Animal Sciences, \\ al. 29 Listopada 46, 31-425 Kraków, e-mail: rzhedrza@cyf-kr.edu.pl \\ *correspondence author
}

\begin{abstract}
The aim of this paper is to show the results of a common hamster inventory conducted in 13 counties of Małopolska voivodeship in 2010-2013. First, we verified the data collected in a previous inventory conducted within the area of Małopolska in 2006-2007. Moreover, we searched some areas not included in the previous inventory. Active hamster sites were confirmed or newly discovered in seven counties. In some localities where hamster used to occur in the past, its presence has not been recently confirmed. The main causes of hamster population decline in the Małopolska voivodeship are discussed.
\end{abstract}

Key words: monitoring, distribution, European hamster, limiting factors

\section{INTRODUCTION}

The phenomenon of continuing shrinkage of common hamster (Cricetus cricetus) range throughout Europe (NECHAY 2000) necessitates monitoring of this species. Verification of the data obtained in previous years enables us to determine the location and rate of its disappearance. The habitat preferences of common hamster have been described in many publications (BeKenOv 1998,

Contribution of 26th Meeting of the International Hamster Workgroup, 15-17th November 2013, Poznań, Poland 
Berdyuigin and Bolshakov 1998, Kayser and Stubbe 2003, Surdacki 1971, Ziomek 2011, ZiomeK and BANASZEK 2008). However,the hamster is not currently found in areas that seem to be optimal for its occurrence. On the other hand, reports have appeared on localities not registered earlier (Auguścik and ZıOMEK 2013, MATyseK et al. 2013). Thus, the inventory connected with simultaneous monitoring of environmental conditions allows us to search for causation of hamster occurrence and consequently improve the effectiveness of any actions towards conservation of the species.

The aim of the present paper is to show the results of a common hamster inventory conducted in Małopolska voivodeship in 2010-2013.

\section{MATERIALS AND METHODS}

The common hamster inventory research within the area of Małopolska voivodeship was conducted in the following 13 counties: Brzesko, Chrzanów, Dąbrowa Tarnowska, Gorlice, Kraków, Miechów, Myślenice, Nowy Sącz, Olkusz, Proszowice, Sucha Beskidzka, Tarnów, Wieliczka. The researched counties are presented in Fig. 1.

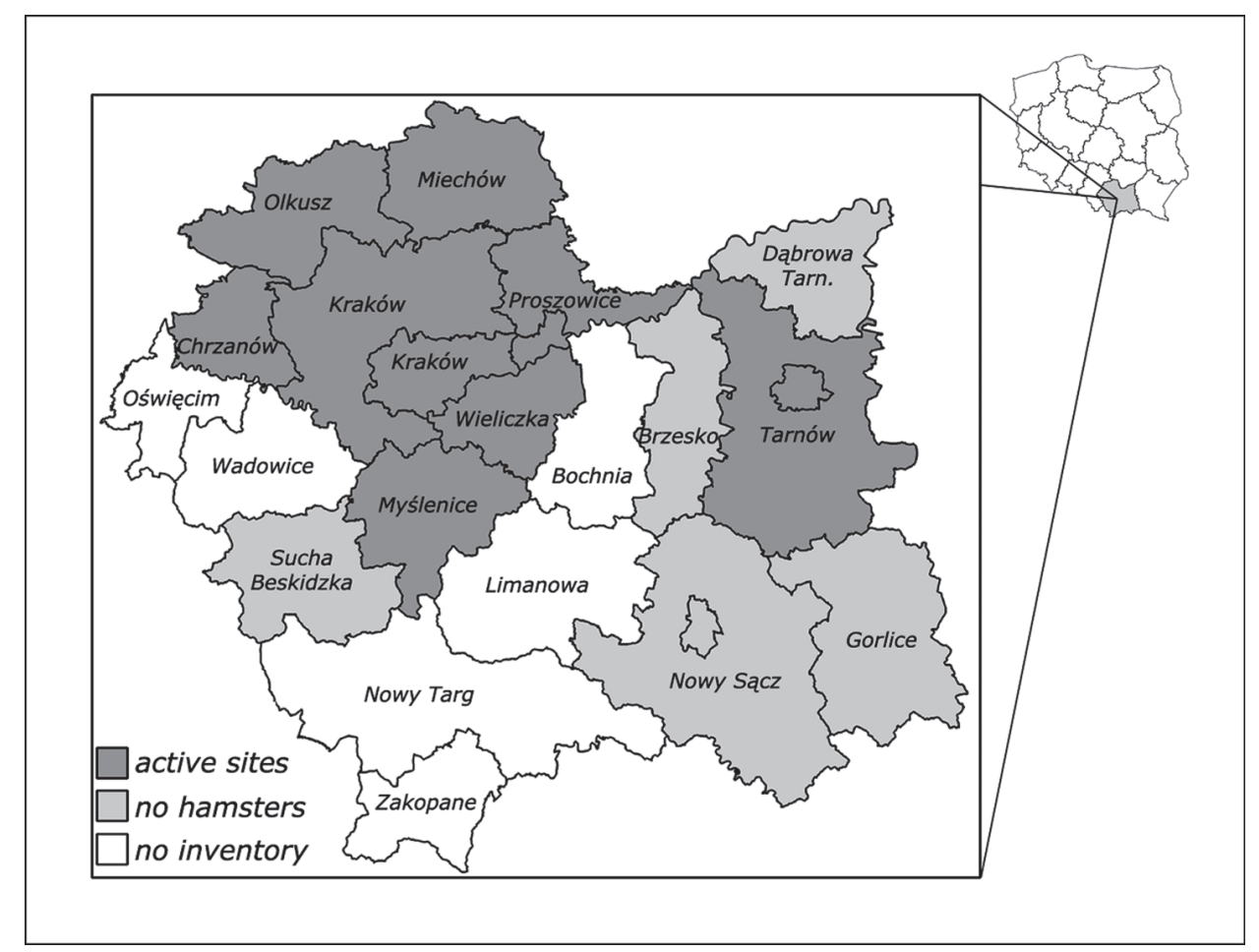

Figure 1. Map of the counties in Małopolska voivodeship, where the inventory of common hamster was conducted 


\section{Study area}

Małopolska voivodeship, is placed partly on The Małopolska Upland, which is one of the sites, besides Lubelska Upland and Roztocze, where common hamster is most common in Poland (ZiomeK and BANASZEK 2007). The total surface area of the voivodeship is $15,187.9 \mathrm{~km}^{2}$ and the area of arable land amounts to $6,830 \mathrm{~km}^{2}$. Within the area of the voivodeship, conditions preventing large scale farming prevail. This is the reason the specific mosaic landscape abounding in field margins. Individual agricultural holdings prevail in the area. According to STATISTICAL YEARBOOK of MAŁOPOLSKA VOIVODESHIP (2011), an average size of holding is 3.80 ha. Farms with an area less than 1 ha $42.5 \%$ of all holdings, and farms over 5 ha. constitute $9 \%$ of all holdings. The agricultural land structure consist of the following: $71 \%$ is arable land, $10.6 \%$ is permanent meadows and $10.1 \%$ - is pastures.

The main cause of agriculture areas transformation is the decrease of agricultural production profitability recorded in the voivodeship. From 2000 to 2011 , a decrease of 159,000 ha of agricultural land and 215,000 ha of crop area were recorded. $4.5 \%$ of arable land is presently set aside. Intensive expansion of towns is taking place. From 2010 to $2011,2,927$ ha had been built-up and 2,393 ha of the voivoideship was afforested (STATISTICAL YEARBOOK of MAŁOPOLSKA VOIVODESHIP 2012).

With the aid of EU-funded projects, communication and transit routes have been developed, which, beside progressing urbanization, enhances habitat fragmentation. Total length of communication routes in Małopolska voivodeship amounts to $23,952 \mathrm{~km}$ (STATISTICAL YEARBOOK of MAŁOPOLSKA VOIVODESHIP 2012).

\section{Localities inventory methods}

To extend our knowledge on the changes in the common hamster range, we verified all the localities so far discovered in the Malopolska voivodeship. The data of the previous inventory in 2006 - 2007 were provided by Joanna Ziomek. Moreover, we searched many areas not included in the previous inventory.

The data were collected by several means:

- Surveys and interviews conducted in 2010-2011 by means of a questionnaire. Overall, 160 interviews and 134 surveys of people inhabiting rural areas were carried out. Apart from questions concerning hamster occurrence, the knowledge on this species was investigated, for instance concerning its legal status or supposed causes of its population decline.

- Fieldwork carried out during vegetative seasons, except for hibernation periods and a flood in 2010 .

\section{RESULTS}

\section{Monitoring results}

The results of common hamster localities verification with reference to the previous inventory conducted in 2006-2007 and the methods applied are presented in Tab. 1 and in Fig. 2. 
Table 1. Information on common hamster occurrence in particular counties of Małopolska voivodeship including results of inventory research conducted in 20062007 at the same sites.

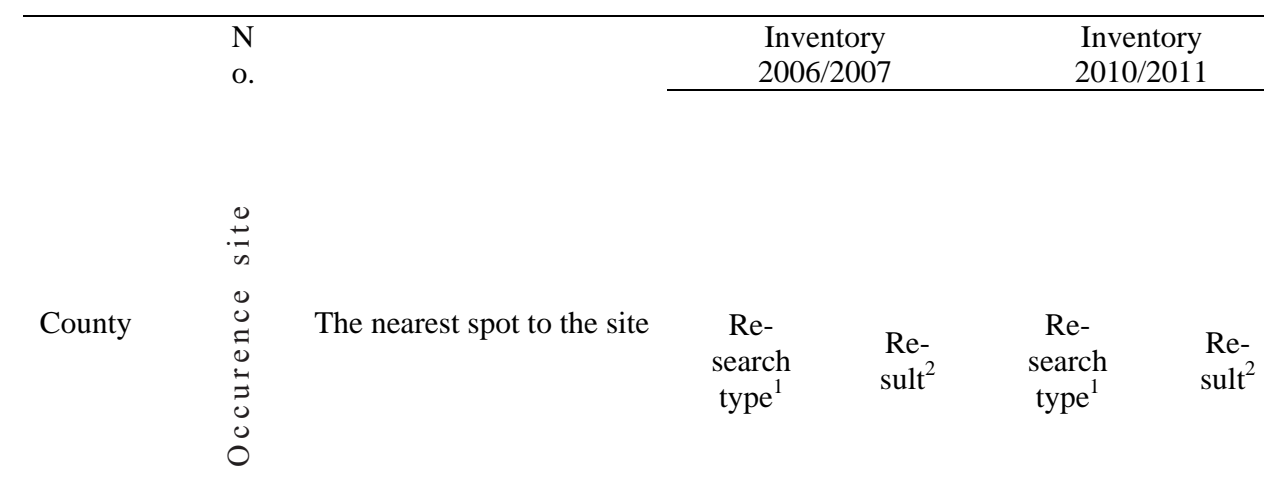

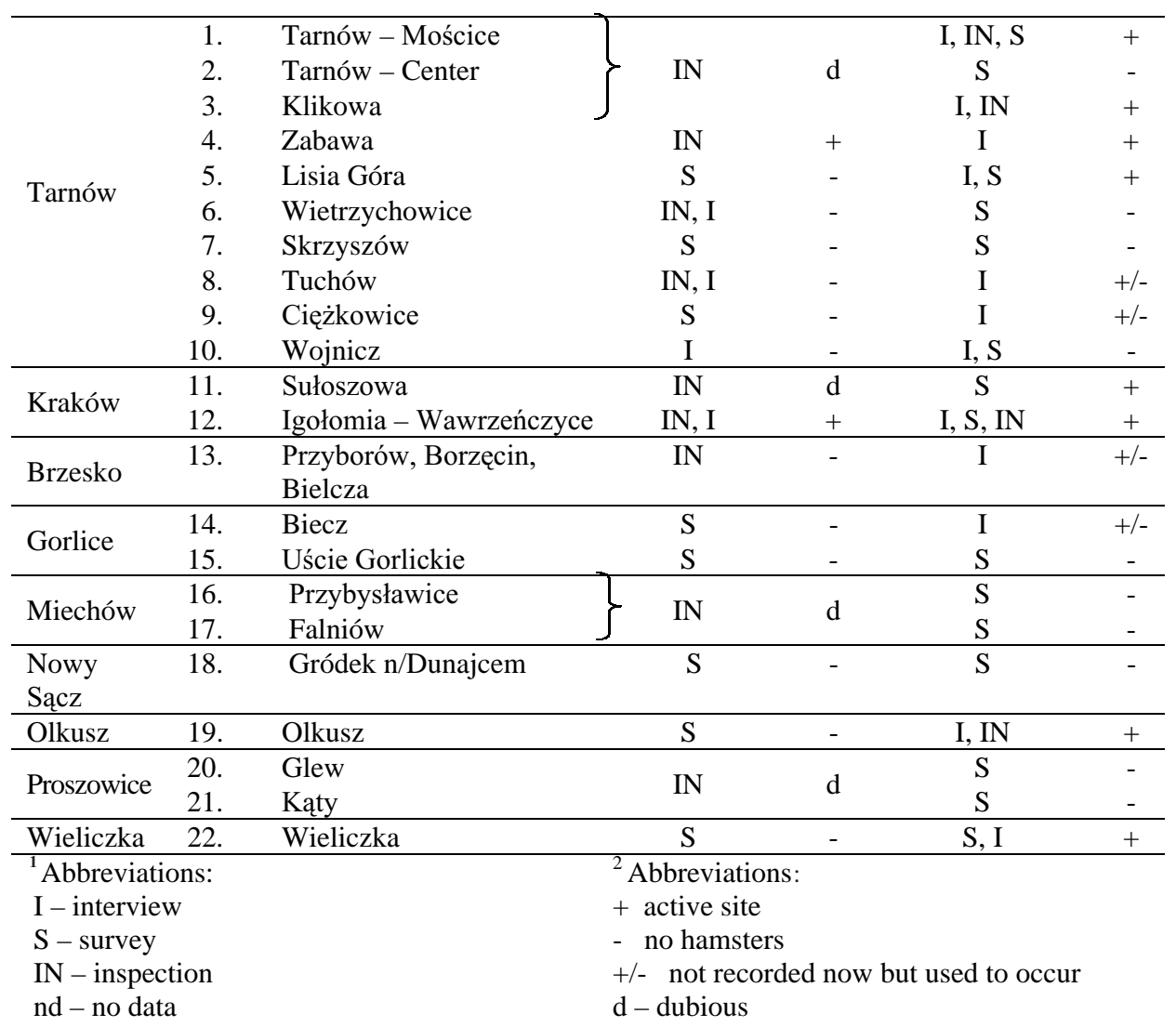


In correlation with the inventory conducted by J. Ziomek's team, common hamster occurrence was confirmed at sites no. 4 and 12 in Table 1 . The negative results of the previous inventory were also confirmed at sites no. $6,7,10,15$, and 18 .

In the inventory conducted by J. Ziomek, some sites were marked as "dubious". These were sites where the likelihood of hamster occurrence was high due to favourable habitat conditions. Among these, common hamster occurrence was confirmed at sites no. 1,3, and 11 in 2010-2013. However, occurrence was not confirmed at sites no. $2,16,17,20$, and 21 previously identified as "dubious". Hamster occurrence was established at sites 5, 19 and 22 where they were not recorded during the previous inventory.

Next, we searched for hamsters in the areas of the Małopolska voivodeship, where monitoring was not conducted in 2006-2007. Results are presented in Table 2 and Figure 2. Site numbering in Table 1 is concurrent with Table 2.

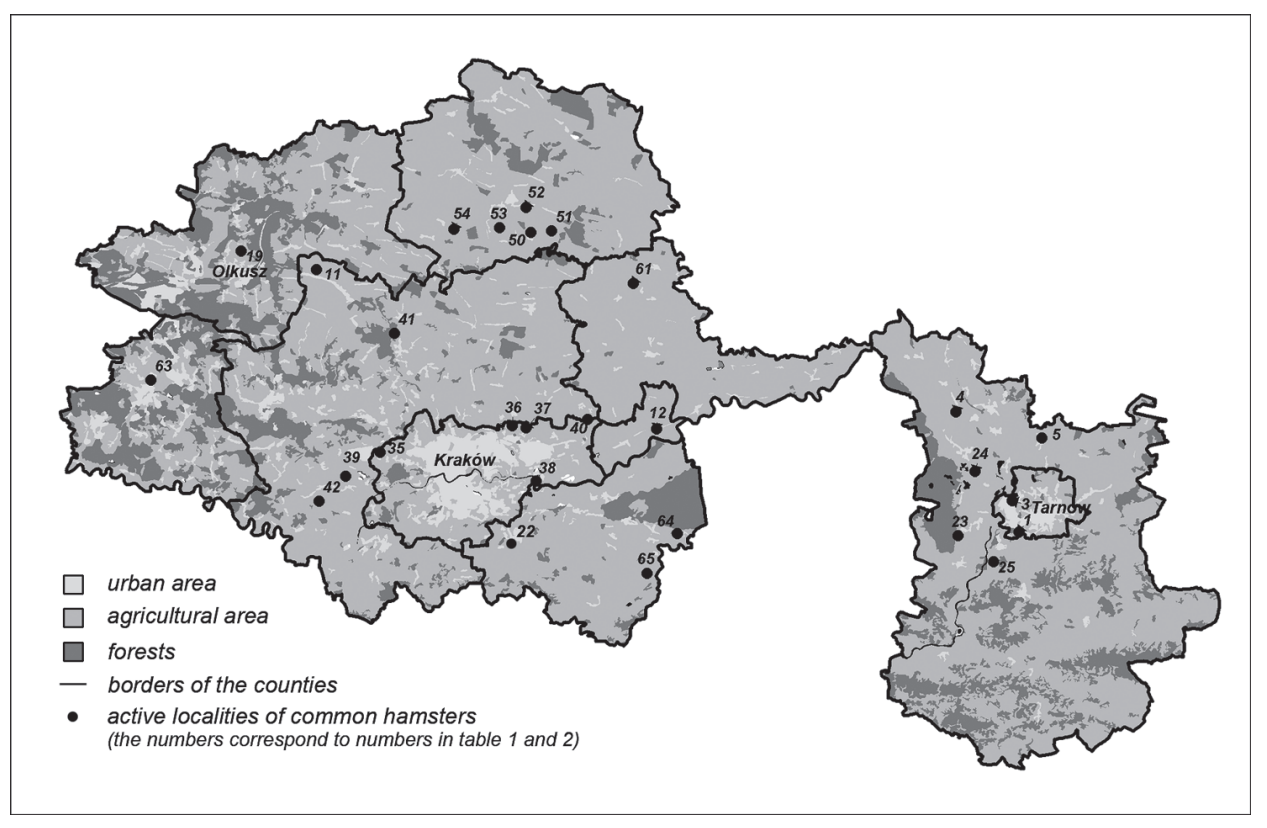

Figure 2. The active localities of common hamster in the counties of Małopolska voivodeship which were surveyed during the presented inventory.

The occurrence of hamsters was established at 20 of the 45 sites from which the monitoring was conducted. In three places, hamster were sighted in the past, but not recently. Four locations were observed on the outskirts of Kraków within the administrative boundaries of the agglomeration.

In localities no. 8 - Tuchów, no. 9 - Ciężkowice, no. 13 - Przyborów, Borzęcin, Bielcza, no. 14 - Biecz, no. 36 - Pleśna, no. 43 - Przegorzały near 


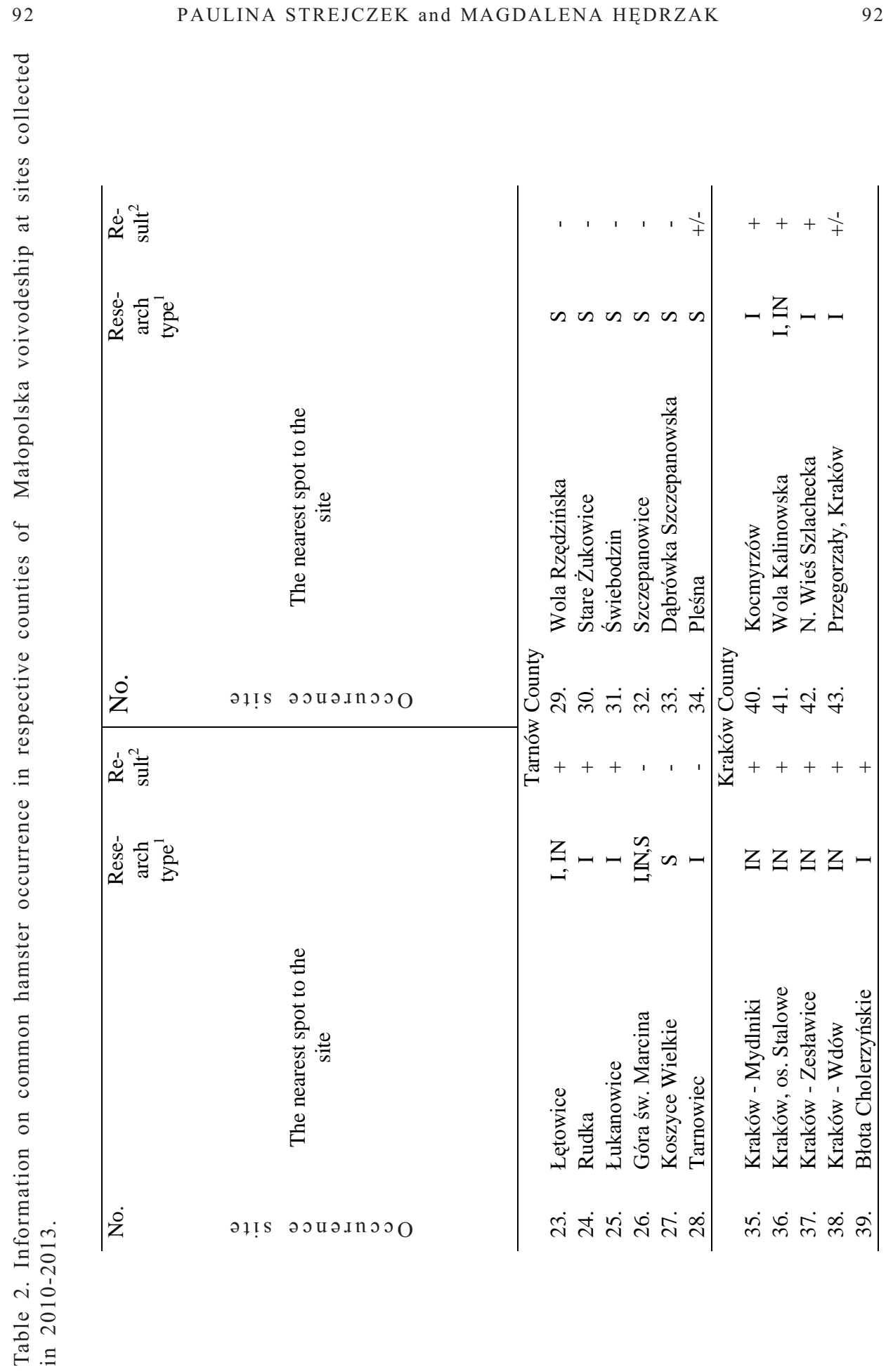




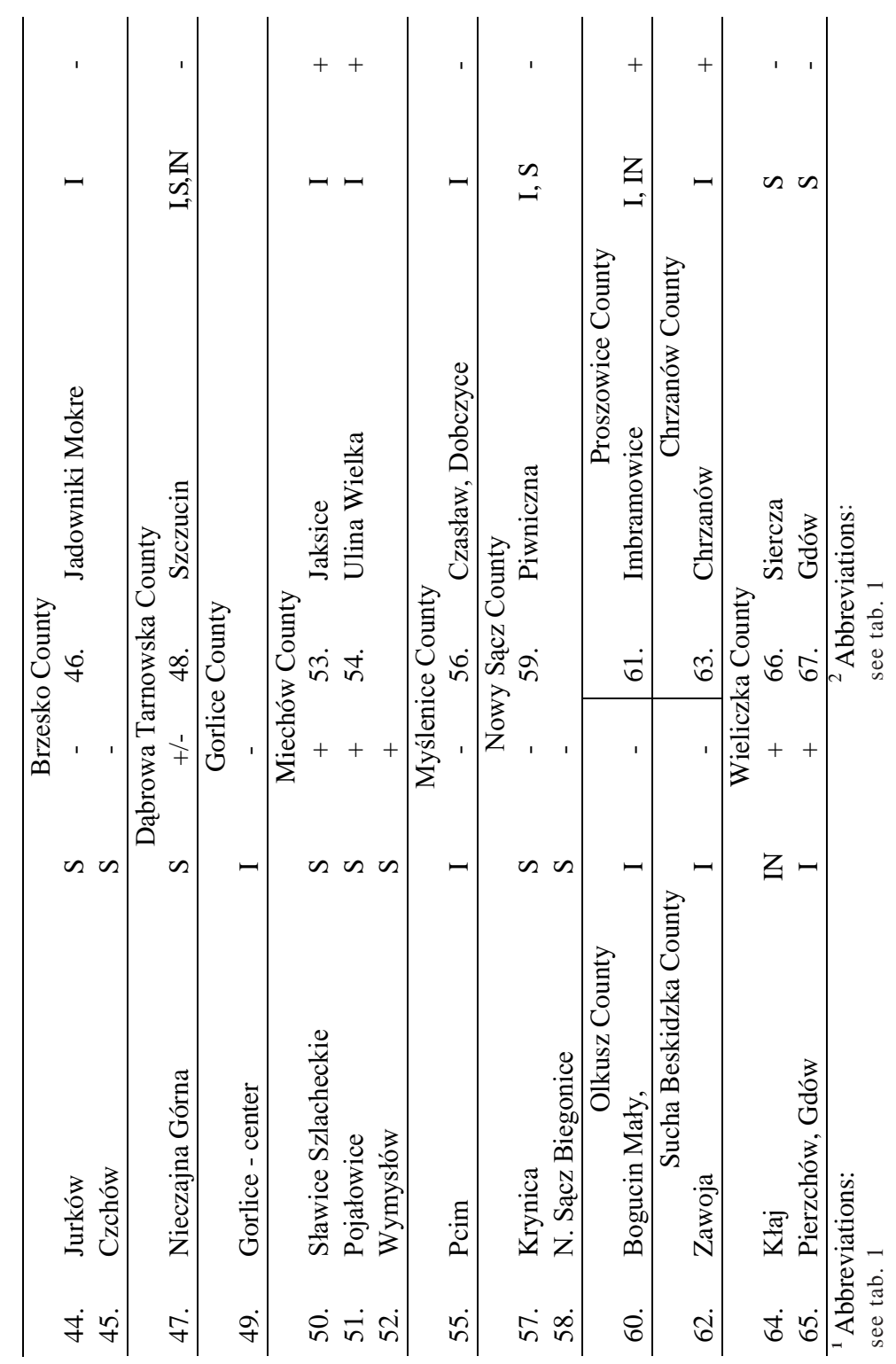


Kraków, and no. 47 - Nieczajna Górna, hamsters were present in the past but had not been sighted recently. Some of the sites were located in agricultural areas that haven't been cultivated recently, which results in overgrowth initiating secondary forest succession. At most such sites, hamsters disappeared over time. This occurred at sites no. 2 - Tarnów - Center - osiedle Westerplatte, no. 8 - Tuchów, no. 9 - Ciężkowice, and no. 13 - Przyborów, Borzęcin and Bielcza. Concurrently, at sites: 36 - Kraków os. Stalowe and 37 - Kraków Zesławice, located within the city but where the land is cultivated, hamster colonies are relatively stable, in spite of the high level of human impact on the environment.

The authors' personal observations at different sites indicate that deep tillage does not always cause destruction of burrows. At some locations it was observed that hamsters simply changed the location of the holes and corridors after this phase of land cultivation.

\section{Interview results}

The results of the survey indicate that knowledge of occurrence and the legal status of the common hamster in Poland is very low. Out of all the respondents, 130 people had never encountered this species nor heard of it. Hamsters were usually identified as pets kept in terraria. 24 people had heard of the common hamster but had never encountered it. Only 38 people directly encountered a specimen, either dead or alive, or the traces of its occurrence such as burrows.

During surveys and interviews, the respondents from agricultural areas were asked about their opinion on causes of disappearance of common hamster sites in proximity to the places of their living.

We present the results being aware that it is only the opinion of farmers, who are not positive about hamsters in many cases and very often kill these animals. According to 35 persons, the main factor contributing to the population decline are wild predators. The most frequently mentioned natural enemies of hamster were: red fox (Vulpes vulpes) $(\mathrm{N}=20)$, marten (Martes sp.) and badger (Meles meles). Hamster sites located in proximity to settlements or even compact urban housing are threatened by frequent visits of wandering dogs and cats. In 18 interviews, inhabitants admitted that a dog (Canis familaris) or a cat (Felis catus) had brought home a hamster, either dead or alive. That happened at sites no. 3- Klikowa, no. 4- Zabawa, no. 24- Rudka and no. 53- Jaksice. Domestic predators probably pose a greater threat within rural areas where walking dogs under the control of their owners is very rare and where pets are sometimes intentionally released without supervision outside the household boundaries.

In ten interviews, respondents admitted to conscious extermination of common hamsters or admitted that they were aware of such activity conducted by local inhabitants or farmers. This applies to sites no. 1 - Tarnów - Mościce, no. 37 - Kraków Zesławice and no. 53 - Jaksice. This kind of activity is motivated by crop protection along with the conviction of necessity to exterminate 
hamsters imparted from generation to generation. Interestingly enough, none of the farmers realised that common hamster are a legally protected species.

Ten farmers declared to consider a possible form of coexistence with hamsters within their farms. However c.a. $75 \%$ of farmers belittled the information regarding hamster legal protection. It is worth noting that, in spite of consistent hamster extermination in some areas, they are annually recorded in constant locations.

In six interviews and four surveys, hamsters killed by traffic were mentioned.

\section{DISCUSSION}

SURDACKI (1971) during the inventory conducted in 1970s, registered active sites of common hamsters in the Małopolska and Lublin Uplands, Roztocze, Western and Eastern Beskids, Mazovian Lowland, Wielkopolska-Kujawy Lowland, Lower and Upper Silesia, and Podlasie.

From the northern Małopolska and Kraków-Wieluń Uplands, the active sites of hamsters began to disappear in the 1990s. This process also has taken place in the southern part of the Wielkopolska-Kujawy Lowland, Głubczyce Plateau, Sandomierz Basin and north-western areas of the Lublin Upland (Zıомек and BANASZEK 2007).

During the inventory conducted in 2000-2005 in the localities visited by SURDACKI in the 1970 s, active burrows of hamsters were found in 103 localities in two isolated areas: the Lublin Upland and Roztocze as well as the southern part of the Małopolska Upland. Single sites have survived in the Sandomierz Basin and the Kraków-Częstochowa Upland (ZiomeK and Banaszek 2007).

In our study, active occurrence sites of common hamster (Cricetus cricetus) were established in seven of the thirteen counties of Małopolska voivodeship. Hamster occurrence was not established in counties: Brzesko, Dąbrowa Tarnowska, Gorlice, Myślenice, Nowy Sącz and Sucha Beskidzka. The highest number of active sites was recorded in the north part of the voivodeship in Kraków, Miechów and Tarnów Counties. The southernmost site is located in the vicinity of Dobczyce Lake, near Pierzchów in Wieliczka County. In some localities where hamster used to occur in the past, its presence has not been confirmed recently. Such sites were recorded in the counties of Brzesko, Dąbrowa Tarnowska, Gorlice, Tarnów and Kraków. We found some localities for this species in places where it has not been recorded earlier. These were in the counties of Chrzanów, Kraków, Miechów, Proszowice, Tarnów, and Wieliczka.

It is necessary to identify the causes of the range decline. Several publications specify numerous factors responsible for the reduction in number and of range of common hamster disappearance such as: formation of large monoculture crops, elimination of alfalfa and red clover crops, decreasing of number and length of field margins, use of chemicals, intensive farming which lessens intervals between harvesting and tillage, set-asides or intentional afforestation of fields, intentional killing of hamsters, thermal instability of winters, develop- 
ment of road infrastructure, wild and domestic species predation (LENDERS and Pelzers 1983, Nowak 2011, Strejczek 2011, Ulbrich and Kayser 2003), transformation of agricultural habitats into built-up areas, land fragmentation, and subpopulations isolation (ZIOMEK 2011, ZiomeK and BANAsZeK 2008). It is difficult to single out the most significant factors in the disappearance of common hamster sites. Unfortunately, the extent of their influence on the rodent population has not been established and neither has their significance been ranked or consequences of their interaction estimated.

It is difficult to say what is the most important factor limiting the occurrence of common hamster in the Małopolska voivodeship. ZIOMEK and BANASZEK (2007) wrote that the rate of the disappearance of the common hamster from a single mesoregion in Poland differed. In their opinion, "it is probably connected with the level and rate of man-made changes in vegetation landscapes and with the intensification of agriculture, as well as with the history of the development of regions and land-use patterns". Intensive agriculture is not conducted in Małopolska, but in many places the arable land is presently setaside. In our study, we observed that at most sites which were located in agricultural areas that haven't been cultivated recently, secondary forest succession has started and the hamsters have disappeared.

Among recorded active sites of hamsters, some of them seemed to be endangered by predators. It concerned the sites adjacent to woodlands, such as no. 19 - Olkusz, no. 13 - Przyborów, Borzęcin, Bielcza, no. 41 - Wola Kalinowska and no. 64 - Kłaj. At these localities, hamsters burrows were few in number. For such subpopulations, even small numbers of predators can be dangerous (FrANKHAM 2005).

One of the most serious issues endangering hamster populations is the fragmentation of their habitats. It can be particularly noticed within the area of such counties as Tarnów and Miechów, where large areas of fields are intersected by freeways or communal roads with a high intensity of motor traffic.

The continuation of common hamster monitoring within the area of Małopolska voivodeship seems to be necessary. Monitoring should include the search for new sites and observation of changes at established localities of hamster occurrence in order to examine range loss causes. This will enable the initiation of effective actions in order to restrain this process.

No conservation project for $C$. cricetus has been initiated in Małopolska voivodeship thus far. Therefore, intensification of actions aimed at this species conservation in the near future seems to be necessary. The level of knowledge on occurrence and legal status of common hamster C. cricetus among inhabitants of Małopolska is very low. Thus, the initiation of an educational project for people from rural areas is essential in order to form a baseline for future conservation actions.

\section{Acknowledgments}

We would like to thank the people who helped us search for sites of common hamsters in Małopolska voivodeship. Special thanks to Zdzisław Bednarz, Zbigniew Bonczar, Andrzej Brzychczy, Mieczysław Dziura, Teresa Gdowska, Henryk 
Iwaniec, Jakub Jaźwiński, Iwona Kaim, Jolanta Majcher-Łoś, Marcin Matysek, Piotr Nowak, Marcin Pieszka, Paweł Strejczek, Klaudia Wszołek, Łukasz Ziewacz and Joanna Ziomek.

\section{WYNIKI INWENTARYZACJI STANOWISK CHOMIKA EUROPEJSKIEGO (CRICETUS CRICETUS) PRZEPROWADZONEJ NA TERENIE WOJEWÓDZTWA MAŁOPOLSKIEGO}

\section{STRESZCZENIE}

W latach 2010-2013, w obrębie granic województwa małopolskiego, przeprowadzona została inwentaryzacja stanowisk chomików na terenie 13 powiatów: Brzesko, Chrzanów, Dąbrowa Tarnowska, Gorlice, Kraków, Miechów, Myślenice, Nowy Sącz, Olkusz, Proszowice, Sucha Beskidzka, Tarnów, Wieliczka. W ramach inwentaryzacji przeprowadzono weryfikację stanowisk wyznaczonych podczas monitoringu, który miał miejsce w latach $2006-2007$. Przeprowadzono także monitoring w miejscach, których nie obejmowała poprzednia inwentaryzacja. Inwentaryzację prowadzono w oparciu o wywiady $(n=160)$ i badania ankietowe $(\mathrm{n}=134)$, oraz o badania terenowe.

Czynne stanowiska zarejestrowano w 7 powiatach, przy czym najwięcej w krakowskim, miechowskim oraz tarnowskim. Nie odnotowano obecności chomika w 6 powiatach: brzeskim, dąbrowskim, gorlickim, gdzie występował w przeszłości, a także w myślenickim, nowosądeckim oraz suskim. Zanik kilku stanowisk, w których chomik występował w przeszłości odnotowano także na terenie powiatu tarnowskiego i krakowskiego.

Podczas prowadzonych badań stwierdzono bardzo niski poziom wiedzy na temat chomików. Osoby niezwiązane z rolnictwem często nie miały świadomości występowania takiego gatunku w Polsce (130 na 294 respondentów). Większość rolników nie ma świadomości, że jest to gatunek chroniony i nie bierze pod uwagę konsekwencji prawnych wynikających z celowego niszczenia nor czy zabijania tych gryzoni. Jako główne przyczyny zaniku stanowisk chomików respondenci $\mathrm{z}$ terenów wiejskich podawali drapieżnictwo dzikich i udomowionych drapieżników, przekształcanie terenów rolniczych oraz śmiertelność na drogach. W kilku przypadkach przyznali, że sami przyczyniają się do ograniczania liczebności chomików poprzez ich celowe zabijanie.

\section{REFERENCES}

Auguścik L., Ziomek J. 2013: Confirmation of the locality of the common hamster in the central part of Lower Silesian Province. Abstract Book, 20th Meeting of the International Hamster Workgroup, 15-27 $7^{\text {th }}$ November, Poznań, Poland: 27.

BeKenov A.B. 1998: Ecology of the Common hamster (Cricetus cricetus) in Kazakhstan. In: M. Stubbe, A. Stubbe, Ökologie und Schutz des Feldhamsters. Halle/ Saale: 81-86.

Berdyuigin K.I., Bolshakov V.N. 1998: The common hamster (Cricetus cricetus L.) in the eastern part of area. In: M. Stubbe, A. Stubbe, Ökologie und Schutz des Feldhamsters. Halle/Saale: 43-80.

Frankham R. 2005: Genetics and extinction. Biological Conservation 126: 131-140.

Kayser A., Stubbe M. 2003: Untersuchungen zum Einfluss unterschiedlicher Bewirtschaftung auf den Feldhamster Cricetus cricetus (L.) einer Leit- und Charakterart 
der Magdeburger Börde. Tiere im Konflikt 7. Martin-Luter-Universitäte, Halle-Wittenberg: 1-148.

Lenders A., Pelzers E. 1983: The occurrence of the common hamster Cricetus cricetuson the Northern limits of its distribution area in the Netherlands. Lutra, 28: 95-96.

Matysek M., Hędzak M., Kuc M., Osmolska A. 2013: The occurrence site of the common hamster Cricetus cricetus in Krakow. [In Polish with English summary] Chrońmy Przyr. Ojcz. 69 (5): 430-436.

Nechay G. 2000: Status of Hamsters: Cricetus cricetus, Cricetus migratorius, Mesocricetus Newtoni and other hamsters species in Europe, Nature and Environment Series, No $\mathbf{1 0 6}$.

NowaK A. 2011: The inventory of the predators on the selected localities of common hamster in the Małopolska voivodeship. Master's degree thesis, [In Polish with English summary] University of Agriculture in Kraków (manuscript).

Statistical Yearbook of Mąopolska Voivodeship 2011. Urząd Statystyczny w Krakowie.

Statistical Yearbook of MaŁopolska Voivodeship 2012. Urząd Statystyczny w Krakowie.

StrejczeK P. 2011: The inventory of the common hamster (Cricetus cricetus) in the Małopolska voivodeship. Master's degree thesis, [In Polish with English summary] University of Agriculture in Kraków (manuscript).

SURDACKI S. 1971: The distribution and ranges of the European hamster Cricetus cricetus (Linnaeus, 1758) in Poland. Ann. UMCS, Lublin, Sectio B, 26: 267.285. [In Polish with English summary] Ann. UMCS, Lublin B, 26: 266-285.

Ulbrich K. and Kayser A. 2003: A risk analysis for the common hamster (Cricetus cricetus). Biological Conservation 117: 263-270.

Ziomek J. 2011: The common hamster Cricetus cricetus (L.) in the mosaic of arable fields of southern Poland. Space use, activity and behavioural patterns. [In Polish with English summary] Wydz. Biol. UAM w Poznaniu, Biologica Silesiae, Wrocław.

Ziomek J., Banaszek A. 2007: The common hamster, Cricetus cricetus in Poland: status and current range. Folia Zoologica 56 (3): 235-242.

Ziomek J., Banaszek A. 2008: The common hamster. [In Polish with English and German summary] Wyd. Klubu Przyrodników. Świebodzin. 